\title{
Human Agency, Entrepreneurship and Regional Development: A Behavioural Perspective on Economic Evolution and Innovative Transformation
}

\author{
Robert Huggins - Cardiff University \\ email: HugginsR@cardiff.ac.uk \\ Piers Thompson - Nottingham Trent University \\ email: piers.thompson@ntu.ac.uk
}

\begin{abstract}
An emerging position within theories of entrepreneurship and regional development concerns the role of human behaviour. This paper argues that the type and nature of human agency, in particular that relating to entrepreneurship, is a significant factor in explaining their capacity to achieve economic evolution through renewal and innovative transformation. It is argued that the regional economic ecosystems are a primary result of the agency of a particular cadre of individuals; with the nature of these ecosystems being contingent on the underlying culture and institutional environment within a specific region. Furthermore, it is proposed that the confluence of group level culture within a city or region and the personality psychology of individuals results in a psychocultural environment that creates certain forms of human agency that determines the nature of entrepreneurship. Similarly, the propensity toward entrepreneurial agency will be at least partly determined by the nature of the underlying regional economic ecosystems, especially with regards to apparent opportunity and economic returns. Drawing on these insights, the study outlines the implications for policies that seek to support entrepreneurship at the regional level, while also identifying future research required to further effective policy intervention.
\end{abstract}

\section{JEL Codes: 01; 012; 018; 043; P48}

Please cite this article as follows:

Huggins, R and Thompson, P. (2019) 'Human Agency, Entrepreneurship and Regional Development: A Behavioural Perspective on Economic Evolution and Innovative Transformation', Entrepreneurship and Regional Development, doi: $10.1080 / 08985626.2019 .1687758$

This is an Accepted Manuscript of an article published by Taylor \& Francis in Entrepreneurship and Regional Development on $24^{\text {th }}$ November 2019, available online: https://doi.org/10.1080/08985626.2019.1687758 


\title{
Human Agency, Entrepreneurship and Regional Development: A Behavioural Perspective on Economic Evolution and Innovative Transformation
}

\begin{abstract}
An emerging position within theories of entrepreneurship and regional development concerns the role of human behaviour. This paper argues that the type and nature of human agency, in particular that relating to entrepreneurship, is a significant factor in explaining their capacity to achieve economic evolution through renewal and innovative transformation. It is argued that the regional economic ecosystems are a primary result of the agency of a particular cadre of individuals; with the nature of these ecosystems being contingent on the underlying culture and institutional environment within a specific region. Furthermore, it is proposed that the confluence of group level culture within a city or region and the personality psychology of individuals results in a psychocultural environment that creates certain forms of human agency that determines the nature of entrepreneurship. Similarly, the propensity toward entrepreneurial agency will be at least partly determined by the nature of the underlying regional economic ecosystems, especially with regards to apparent opportunity and economic returns. Drawing on these insights, the study outlines the implications for policies that seek to support entrepreneurship at the regional level, while also identifying future research required to further effective policy intervention.
\end{abstract}

\section{JEL Codes: O1; 012; 018; 043; P48}

\section{Introduction}

Theories relating to the economic development, transformation and the evolutionary renewal of cities and territorial regions are largely based on a multiplicity of explanations relating to the location, agglomeration and organisation of firms, industries and capital. A host of factors relating to the availability of capital in the form of investment and resources, the skills of the workforce, the availability and capability of entrepreneurs and other agents of innovation, as well as the cooperation and collaboration achieved through ecosystems, are all offered as explanatory factors (Capello and Nijkamp, 2009; Cooke et al., 2011; Stimson et al., 2011; Spigel, 2017; Shearmur et al., 2016). In general, these approaches echo the notion of regions as 'Schumpeterian hubs' for recombining human capital in order to generate innovation (Wolfe, 2017). In particular, notions relating to ecosystems and agency suggest that merely investing in capital may not be enough to secure entrepreneurship leading to greater innovation and high rates of economic growth, especially the type of transformative renewal that is required in industrially mature and economically lagging regions.

An emerging position within regional development theories concerns the role of human behaviour and institutions in shaping and moderating this behaviour (Huggins and Thompson, 2016; Rentfrow and Jokela; 2017; Lee, 2017). Principally, the focus is on entrepreneurial human behaviour and the means by which such behaviour drives innovation and subsequently economic development. Stemming from this, the paper seeks to address a fundamental research 
question: how does the type and nature of human agency existing within cities and regions at particular points in their development explain a significant factor in their capacity to achieve economic transformation and renewal? In particular, it seeks to set notions of entrepreneurial human agency within wider and emerging theories of regional economic evolution and innovative transformation. It is suggested that while the configuration and capability of economic ecosystems - which are conceptualised through notions such as clusters, innovation systems and industrial districts - determine regional development outcomes, at the micro-level it is the role of certain key human agents within regions who actually shape the nature and evolution of these ecosystems. Therefore, a second research question is: what factors determine the emergence and evolution of the types of human agency that results in entrepreneurship in particular cities and regions that fosters development and transformation? As a result, it is argued that human agency is likely to be one of the key rooted drivers associated with more traditional explanatory causes of economic development and transformation, and should be considered seriously when addressing the routes available to economically mature regions in their bid to foster renewal and transformation.

It has been increasingly argued that human agency is based on a rationality that is spatially bounded (Huggins and Thompson, 2017a; Pike et al., 2016). In particular, cities and regions themselves produce a spatially bounded rationality that determines the forms and types of human agency apparent in a given city or region, and subsequently the nature of knowledge, innovation, and development. For example, it is argued that entrepreneurship, innovation and creativity are social processes that involve groups of people who build off one another historically, and are the products of cities and regions that act as the key organizing unit for these activities, bringing together the firms, talent and other regional institutions necessary to support entrepreneurship (Florida et al., 2017). Similarly, the symbiotic relationship between key agents and their location is found in research relating to the role of a limited number of "star" scientists in promoting the innovation performance of certain cities and regions (Zucker et al., 1998; Moretti, 2012).

Fundamentally, agency refers to acts done intentionally, and the key argument put forward in this paper is that during periods of economic and innovative transformation in particular cities and regions there will be a relatively small number of key human agents that are the core, but not necessarily sole, drivers of such development. Through such agency, regions can become 'incubators of new ideas' and provide opportunities for entrepreneurship to take place, as well as for discovering valuable new knowledge (Huggins and Williams 2011; Hülsbeck and Pickavé, 2014). Successful urban and regional economic transformation may 
emerge from forms of agency that promote institutional and cultural change, especially through the introduction of economically efficient institutions and cultural change and diversity across time. Regions that are unable to effectively transform economically and industrially may be marked by agents that promote institutional and cultural persistence, in particular through rentseeking institutions, and cultural reproduction and homophily across time.

In order to address the research questions, the paper critiques the literature that examines the role of human agency in facilitating the undertaking of entrepreneurship to positively influence regional development. The study seeks to establish the role of entrepreneurial agency within the regional development context. This is examined in terms of agents acting directly as entrepreneurs, and also with regard to those agents who support the entrepreneurial endeavours of others by helping to establish the institutions required. From this, the paper seeks to determine implications for those policymakers seeking to encourage regional entrepreneurship, and where further research of various types are required.

As a means of navigating a critique of a range of literature that does not always engage with each other, the paper is organised along the following lines. At the outset, existing theories of regional evolution and development are examined as they form the overarching perspectives of the micro-mechanisms that we are seeking to understand (section 2). To enable a drilling down on these specific micro-mechanisms, the paper provides an overview of the integration of behavioural theories into explanations of entrepreneurship and its role in helping generate regional development, followed by a critique of the complex and disputed relationship between agents and structure (section 3). To explain the role of human agency in these systems in a more concrete manner some short historical accounts are utilised to consider practical evidence concerning the theoretical relationships previously addressed (section 4). Finally, some discussion and overall conclusions are provided relating to the theoretical contribution of the paper, policy implications and a future research routes (section 5).

\section{Theories of Regional Evolution}

This section examines a series of literature that considers the evolution and development of regions and their institutions within them. This work is utilised later in the analysis to understand the role played by key individuals within a region, including both entrepreneurs and those that generate supportive institutions and cultures for entrepreneurs to successfully operate within. As a starting point, one example of a general regional evolutionary framework has described a process of genesis, development, growth, renewal/demise (Huggins, 2008). A genesis phase is usually the result of an institutional trigger that acts as an initial magnet for 
attracting talented agents particularly entrepreneurial individuals, and although they may not necessarily be a single institution, there is a high degree of correlation with the existence of specific universities and research institutes within a regional 'cluster' (Harrison, Cooper, and Mason, 2004; Moretti, 2012). The development phase of a region is based on forces that spin off knowledge from the institutional trigger, which remains localized, whilst the growth phase occurs when a region successfully develops a critical mass, acting as a centripetal magnet for new capital inputs and agents (Ter Wal and Boschma, 2011). The renewal or demise stage of regional development is largely dependent on the technological trajectory or path of its product and process base (Boschma and Martin, 2010). Regions that are able to adapt to disruptive knowledge shifts, through the creative destruction associated with new product and market development, will survive and grow, whereas those regions that have become overly path dependent will enter the demise stage (Peterson, 2000).

Perhaps the most important feature of economic renewal is the requirement for the continual development and mobilization of human capital. This is strongly related to the capacity to renew networks and create new modes of interaction, often with actors who are one step removed - indirect ties - from existing associations (Martin and Sunley, 2011). If one examines perhaps the most resilient and self-transformative of all regional economies in the modern era, Silicon Valley, it is found that firms of all sizes interact in the ecosystem, in which superior technology trumps business size, with innovation occurring in a highly decentralized environment, with the benefits of proximity - dense social and professional networks, informal information exchange, cross-firm collaboration, and serendipity - outweighing the high and rising costs of being in the ecosystem (Saxenian, 1994; Saxenian and Sabel, 2008; Spigel, 2015).

The fundamental thrust of regional evolutionary theory is that innovation no longer occurs in isolated laboratories, but through collaborative co-development networks between increasingly specialist producers, i.e. connected and collective agency. At all stages of the production process, innovation is a highly iterative and non-linear process. Learning happens through continuing interactions facilitated by social networks and open labour markets, which allows know-how and information to circulate freely (MacKinnon et al., 2002). It is possible to contribute to the formation of such an ecosystem, but it cannot be easily planned from the top down, and once it begins to emerge, the strength of such a system is that it fosters unanticipated re-combinations of skill and technology, and multiple, often parallel, experiments with technology, organisation, markets, and so forth (Saxenian and Sabel, 2008). In essence, the emergence of Silicon Valley perhaps best represents an empirical example of 
the agency-system paradigm presented by some evolutionary economists (Dopfer et al., 2004; Dopfer and Potts, 2004).

In older industrial regions where there has been a process of demise, rather than renewal, de-industrialisation results in capital flight. As Harvey (2003, pg. 116) notes, "if capital does move out, then it leaves behind a trail of devastation and devaluation; the deindustrializations experienced in the heartlands of capitalism... in the 1970s and 1980s are cases in point", giving rise to the many problems associated with old industrial regions. Martin and Sunley (2011) argue that the evolution of regional economies can be best analysed by considering them to be manifestations of complex adaptive systems consisting of numerous components with functions and interrelationships that provide the system with a particular identity and a degree of connectedness, with the adaptive perspective highlighting the importance of recombination and reuse of resources. Renewal, they argue, depends on reworking the legacies from preceding economic cycles, particularly through the engagement of 'extrovert' entrepreneurs. Martin and Sunley (2011) further suggest that the microbehaviours - or agency - of individual system components (individuals and firms) are the most significant factor for evolutionary courses during periods of change and transition.

As a general schematic, regional evolutionary frameworks are at pains to highlight the importance and focus on the 'collective' nature of regional development, and although certain examples confirm this, more generally across many regions may lack a realism as coordination mechanisms may not provide such 'harmonious' development if such coordination does not stem from the form of the culture and informal institutions that guide, promote and constrain particular activities. However, such cultures and institutions are not fixed, and may be shaped by human agents within regions, in the form - for example - of entrepreneurs and policymakers, in particular, into a cultural and institutional environment that is more conducive to innovative transformation, renewal, and economic development. This sounds intuitively plausible, and suggests that theories of regional evolution need to better incorporate the role of the coordinating and constraining influence of culture and institutions, discussed in the next section, alongside the mechanisms by which entrepreneurs and other agents are influenced by, and influence on, these cultures and institutions.

\section{Behavioural Explanations of Regional Development}

Explanations of development, evolution and transformation across regions are generally rooted in factors based on the structure, dynamics and organisation of firms, industries and capital. Emerging theories, however, are moving toward a (re)turn to addressing the role of individual 
and collective behaviour in determining regional development outcomes (Obschonka et al., 2013b). Such an influence is likely to travel in both directions from structure to individual behaviour, and individual behaviour to structure (Sarason et al., 2006). A number of concepts relating to the behaviour of individuals and groups of individuals have taken an increasingly central role in shaping an understanding of why some places are better able to generate higher rates of development and innovation, and avoid the low-road development trajectories and associated higher rates of inequality found in weaker regions (Tabellini, 2010; Tubadji, 2013).

Given a range of theoretical developments in recent years already indicated, it would appear appropriate to examine behavioural explanations of entrepreneurially driven regional development, innovative transformation and renewal. Based on thinking from behavioural economics, some scholars suggest that individual decision-making results from local influences experienced through situations. Such 'situations' equate to the dominant cultural traits embedded within the local communities where these 'influences' are formed (Storper, 2013). The rise in importance given to cultural values in regional development theory has led to the emergence of a 'new sociology of development' that entwines the role of geography with factors relating to individual and collective behaviour (Sachs, 2000; Hadjimichalis, 2006; Spigel, 2013). As Clark (2015) argues, human behaviour is fundamental to the social sciences in terms of understanding what people do, where and why they do it, and the costs and benefits of this behaviour. In order to understand the 'aggregate' differences in socio-economic activities and performance there is a need to explore how these difference stem from the experiences and actions of individual actors (Ariely, 2008; Storper, 2013).

More particularly, the issue of how cultural factors impact on entrepreneurial-led urban and regional development has been increasingly debated in recent years (Spigel, 2013; Tubadji and Nijkamp 2015). Furthermore, recent work on socio-spatial culture and the spatial nature of personality psychology has sought to address knowledge gaps relating to the role of context and environment in shaping behaviour, often with regard to the promotion of entrepreneurship (Beugelsdijk, 2009; Obschonka et al., 2013). From this psychological perspective, Obschonka et al. (2015), for example, draw from the Five-Factor Theory of Personality - the Big Five traits, which is the predominant personality model in contemporary psychological science to explain such differences in behaviour across places. Rentfrow et al. (2013), for example, have identified three psychological profiles of regions - friendly and conventional, relaxed and creative, temperamental and uninhibited - covering the U.S. states. They find that in terms of economic prosperity a positive link exists with openness and extraversion, while 
conscientiousness displays a negative association. Taken together, it can be suggested that culture and personality psychology form the psychocultural behaviour of a city or region.

These psychocultural behaviours have the potential to be persistent and deeply rooted in previously dominant economic activities, so that their influence is felt many decades later. For example, a historically high level of mining is found to be associated with lower entrepreneurial activity (Glaeser et al., 2015), positive attitudes to collective behaviour in the form of unionism (Holmes, 2006), and preferences against redistribution (Couttenier and Sangier, 2015). Therefore, in the context of mature regional economies in advanced nations such as the UK, there are strong reasons to suggest that the concentration of large-scale coalbased industries in these regions have left a lasting psychological imprint on local culture of the old industrial regions, with selective outmigration resulting in more optimistic and resilient individuals with positive and agentic mindsets seeking new environments that offer new economic opportunities. This eventuates in an indigenous population in the home region lacking in 'entrepreneurial spirit (Stuetzer et. al. 2016; Obschonka et al., 2017). Others suggest that these regions now suffer from a case 'social haunting', whereby there is a kind of 'ghosted' affective atmosphere that has endured long after the traditional industries associated with these regions have disappeared (Gordon, 1997; Bright, 2016).

In general, an acknowledgment of these cultural and psychological factors have given rise to calls to examine the role of behavioural traits in promoting or hindering regional renewal, resilience and transformation (Martin and Sunley, 2015). Thompson and Huggins (2018) argue that less is known concerning how the interaction between the psychological factors that may more typically affect entrepreneurs at the individual level and group held cultures impact on development outcomes. In particular, they suggest that culture may combine to influence entrepreneurship through three routes: (1) an aggregate trait view; (2) a legitimation or moral approval route; and (3) a push effect. In the case of the aggregate view, culture simply facilitates the creation or attraction of more individuals with entrepreneurial personality traits (Uhlaner and Thurik, 2007; Obschonka et al., 2013b; Stuetzer et al., 2016). This implies that culture operates through the entrepreneurial personality rather than moderating its influence. However, in terms of legitimation there is no increase in the number of individuals that display entrepreneurial personality traits, but the support provided or not provided by the dominant culture determines whether the marginal entrepreneur chooses to engage or not (Kibler et al., 2014). Noorderhaven et al. (2004) provide an alternative perspective whereby entrepreneurship provides an outlet for those dissatisfied with the mainstream. This is also compatible with the findings of psychologists such as Obschonka et 
al. (2013a) who find that those involved in rule breaking in their formative years are more likely to be entrepreneurs.

Although studies have examined the relationship in terms of 'fit' between the individual and the average personality traits present and its impact on well-being (Jokela et al., 2015), studies seeking to understand the multi-level relationship between culture and personality and entrepreneurship are rare, but appear a fruitful root for providing a fuller explanation of the emergence of entrepreneurship within the regional context. Empirically, studies have found more support for the legitimation perspective, but as all three could be at play, and there is a need to understand these relationships in more detail, theoretically point to a requirement for a deeper knowledge of the agent-structure nexus. In this case, entrepreneurs are agents responsible for creating the structure within which they operate and also are influenced by it, whereby economic systems emerge from human behaviour and interaction, with the system 'made' of economic agents and the rules they carry as well as their role in the adoption and adaptation of these rules (Dopfer et al., 2004; Dopfer and Potts, 2004).

In the structuration theory proposed by Giddens $(1979,1984)$, structure in the form of social and economic systems provides the underlying conditions that bound, yet do not determine, the activities of particular agents (Moos and Dear, 1986). Through this theoretical approach Giddens $(1979,1984)$ has sought to reconcile part of the on-going tension within both cultural and institutional analysis in relation to the connection between the impact of economic and social structure and the agency of individuals operating within these structures. Within this framework, agents are considered to be active, knowledgeable, reasoning persons and are key to the analysis of subsequent outcomes (Moos and Dear, 1986; Rodríguez-Pose, 1998).

Drawing on this theory, Sarason et al. (2006) argue that opportunities are not just waiting to be discovered, but are created through the conceptualisation and development of the entrepreneur. Opportunities are the structure, but the entrepreneur as the agent has causal power. However, structure mediates and determines this causal power. At the same time, the entrepreneur can influence these structures rather than taking them as set and pre-determined. Therefore, there is a dualism that suggests that the entrepreneur and their potential opportunities cannot be understood separate from one another (Sarason et al., 2010). Within this line of thinking, Mole and Mole (2010) draw on a critical realism perspective to argue that some structures such as social norms and culture cannot be immediately altered by entrepreneurs. Instead, agents rarely want structure in its current form as created by past agents (Archer, 1995). Current agents are also not fully knowledgeable of the society element of structure (Archer, 2003). Sarason et al. (2010) highlight that there may be more stable elements 
of structure, but these influences depend on how agents interact with them. Instead, agents may not create structures at will, but structures cannot exist without the agent. Given this, the creation and maintenance of opportunities is reliant on entrepreneurs, without being fully under their control.

Building on notions of bounded rationality, scholars such as Porter (1981) argued that there is need for a more agentic position of understanding economic development whereby agents in the form of entrepreneurs and managers are able to exercise power in their choice of markets and other options that are not pre-determined by the underlying structure of the industry in which they are positioned. In due course, Porter (1990) developed his thinking further through his examination of the concept of regional systems of 'clusters', which he considered help capture important linkages, complementarities, and spillovers of technology, skills, and information that cut across firms and industries. In this sense, Porter is discussing an ecosystem that connects economic agents to provide value - in the form of productivity gains, innovation and entrepreneurial opportunities - for each (Huggins and Izushi, 2011).

Some regional systems are able to renew themselves and evolve through entrepreneurship and innovation and often develop a morphological capacity to remain comparatively competitive often through periods of national or global recession (Saxenian and Sabel, 2008). The flexibility of SMEs and entrepreneurs is a key part of this, as they allow adaptation to exogenous shocks and even enable them to take advantage of the opportunities created by disequilibrium through innovation (Smallbone et al., 2012; Cowling et al., 2015). Regions with a capacity for renewal must subject themselves to innovation, dynamic change and evolving processes, imposed by entrepreneurial individuals in much the same way as products have to change if they are to alleviate the risk having a short shelf life. However, it is not necessarily the case that all regions have entrepreneurial cultures that are resilient themselves when hit by negative economic shocks (Huggins and Thompson, 2015; Thompson and Zang, 2018). As Ter Wal and Boschma (2011) indicate, at the maturity stage of regional evolutionary economic system there is either a shake out of declining firms and industries that positively leads to the start of a new cycle, or a long-term period of locked-in decline.

The questions this leads to is: what is the role of the agentic power of entrepreneurs in the emergence and establishment of these new cycles. Establishing the timeframes and the extent to which different entrepreneurs are able to shape the opportunities available provides a better understanding of their role in regional development. In addition, determining the need and capacity for greater intervention by others to provide a supportive culture and institutions 
is important. To consider this, research on particular types of agency as discussed in the next section provides some pointers

\section{Human Agency, Entrepreneurship and Regional Development}

One approach to conceptualising and analysing agency is methodological individualism, whereby macro-level outcomes are retraceable to individual decision-making agents (Hodgson, 2007). Such approaches stem from the work of McClelland (1967), which suggests a link between the extent to which individual agents are motivated to achieve and the ensuing rates of development of the societies in which these individuals operate. Within the field of social psychology, Bandura's $(1997 ; 2006)$ social cognition theory, primacy is given to the role of 'personal efficacy', which he considers relates to the belief that individuals have in their capability to achieve desired results from their action. However, it should be noted that such expectations are not necessarily perfectly rational but, as previously discussed, bounded by their psychological, cultural and institutional setting. Without such personal efficacy, which Bandura $(1997 ; 2006)$ considers to be the cornerstone for understanding human agency, individuals are unlikely to have the incentive to act in a particular manner.

Fundamentally, to be an agent is to intentionally make things happen by one's actions (Bandura, 2001), and as a means of unpacking and delineating forms of agency that potentially impact on urban and regional development outcomes, the field of psychology provides some interesting pointers. In particular, the social cognition theory proposed by Bandura (2001) distinguishes three modes of agency: personal agency in the form of the power to originate actions for given purposes, although the extent to which such agency has beneficial or detrimental effects, or produces unintended consequences, is a matter for further consideration; proxy agency that relies on others to act on one's behest to secure desired outcomes, and collective agency exercised through socially coordinative and interdependent effort. Some Marxist influenced scholars deny individual or personal agency (Mokyr, 2015), and within the field of regional development theory increasing emphasis has been given in recent years to the role of collective agency through networks of individuals agents and actors (Bristow and Healy, 2014; Cumbers et al., 2016). However, the balance between particular forms of agency is likely to vary across regions precisely due to their differing specific psychocultural behavioural conditions.

A compelling analysis of the role of human agency in propelling economic transformation is provided by Mokyr (2017) who argues that from 1500 to 1700 parts of European society-largely the educated elite-developed a set of cultural traits and 
accompanying institutions that were highly attuned to fostering the forms of intellectual innovation and knowledge that ultimately propelled the Industrial Revolution. Specifically, Mokyr (2017) suggests that key cultural changes relating to the increased value placed on innovation and ideas occurred during this period, and through the formation of a market for ideas, a relatively small number of cultural entrepreneurs across Europe were responsible for driving this cultural change. Mokyr (2017) describes how these entrepreneurs stimulated directly and indirectly economic evolution on an unprecedented scale, with the interaction of cultural evolution and evolutionary biology resulting in the emergence of adaptive agents who chose whether to adopt new ideas from a series of cultural menus that led to intellectual innovation.

Returning to the regional scale, the literature points to three forms of agency that may act as catalysts of transformation: entrepreneurial agency (Drakopoulou Dodd and Anderson, 2007), political agency (Ayres, 2014), and labour agency (Coe and Jordhus-Lier, 2011). Although all are likely to play a role in transformation process, entrepreneurial agents are most usually depicted as the catalysts of economic change that develops cities and regions, often enacting a collective identity that facilitates and shapes development (Lippmann and Aldrich, 2015). From both a spatial and temporal perspective, entrepreneurs have been further conceived as 'generational units' in the sense that they are agents who mould collective memories through space and time (Lippmann and Aldrich, 2015; Huggins and Thompson, 2017a). Crucially, they are highly heterogeneous agents possessing a wide-range of personality traits including extraversion, openness to experience, conscientiousness, and the ability to bear risk (Fritsch and Wyrich, 2015).

At the regional level, rates and types of entrepreneurship often vary greatly, and in more 'entrepreneurial regions', network mechanisms are formed through the evolutionary interdependency emerging between entrepreneurs and other economic agents as a result of the recognition and necessity for knowledge and innovation-based interactions beyond the market (Cooke 2004). Given this, entrepreneurial agency can be considered to operate across the personal-proxy-collective continuum. Most prominently there is the personal agency of individual entrepreneurs, but the networks and collaborations they form with each other conforms to the basis of a collective agency that will impact on urban and regional development outcomes.

Alongside entrepreneurial agency, the agency of those associated with the political economy of cities and regions represents another form of active behaviour that is likely to determine the future of these places. Leading commentators such as Chang (2013) and Piketty 
(2014) highlight the role of political leadership in determining economic outcomes. Arguments to increase the global democratic power apportioned to city and regional level governments, as opposed to national government, are examples of the perceived role of urban and regional level political agency in shaping not only development at a sub-national level but also on the international stage (Barber, 2014; Beer and Clower, 2014). Indeed, a growing literature suggests that the economic performance of cities and regions is linked to the quality of leadership within these places (Stimson et al., 2009). An important implication for regional development outcomes is to consider the interaction between entrepreneurial, political and labour agency in order to understand both positive and negative impact. For example, whereby efforts to boost development are supported, or subverted through rent seeking activities, resulting in particular mixes of different types of agency that allow the exploitation of others.

Following in the footsteps of Mokyr (2017), it is of interest to examine whether his key agent thesis of development at a pan-European level holds up when regional and city territories are analysed. Although a full analysis would require extensive new data collection, one useful and bounded source of information is Peter Hall's (1998) Cities in Civilization. In this book, Hall (1998) describes the evolution of 18 cities and regions at the height of their innovative and transformative prowess on a chapter-by-chapter basis. Although Hall's own analysis may be partial in terms of its coverage, it does give a good indication of the protagonists at the heart of the regional transformation process. Therefore, it is of value to undertake a content analysis of Hall's text in order to identify whether the role proposed for entrepreneurs can be identified.

As part of the results of the content analysis, Table 1 presents a summary of the key agents and the time of their most important agentic activity highlighted by Hall (1998) in nine of the leading cities and regions he describes, ranging from the emergence of Silicon Valley and the Bay Area of San Francisco between 1950 and 1990 to as far back the Roman Empire from 50BC to $\mathrm{AD} 100$. What is marked is that in the majority of cases approximately 20-30 agents are considered to have been the major catalysts that fuelled the urban and regional innovation and development that took place. Within these, there are examples of entrepreneurs who through their innovations changed the direction of the region or city for example (Stephen Wozniak and Steven Jobs (Silicon Valley), Thomas Alva Edison (Los Angeles), Werner von Siemens (Berlin), and Richard Arkwright (Manchester). There are also those civil engineers such as John Augustus Roebling (New York) and Frederick Terman (Silicon Valley) who helped create the infrastructure such as transport links and science parks that vital to allow commence and entrepreneurship to flourish and promote a form of culture and effective institutions required to stimulate development. This begins to suggest that much like Mokyr's 
(2017) arguments regarding the role of an elite group of entrepreneurial agents in triggering the role of the industrial revolution, as well as research on the role of star scientists in underpinning regional innovation success (Zucker et al., 1988; Moretti, 2012), a more historic analysis of urban and regional transformation is likely to pinpoint a relatively small number of agents as being central catalysing forces propelling the evolution of their respective urban and regional ecosystems.

\section{Table 1 About Here}

It is interesting that whilst the US examples largely constitute private sector entrepreneurs, who brought new innovations to the market that have radically reshaped the regional economy and also society. However, the earlier examples of Berlin and, in particular, London see a much more prominent role played by those creating the conditions for entrepreneurs to prosper through public health improvements (for example the John Snow's influence on improvements in the sewer system) and the enforcement of laws (Henry Fielding's work in early police forces).

In order to consider the process of transformative regional evolution a little more closely, Tables 2 and 3 present more detailed findings from the content analysis of Hall (1998) for the cases of the growth of the textile industry in Manchester between 1760 and 1830 and the shipping industry in Glasgow between 1770 and 1890. In both cases it is clear that a series of entrepreneurs, industrialists and intellectuals built on the success of their predecessors in each city through a process of knowledge accumulation and both radical and incremental innovation that typifies the regional evolutionary framework discussed above. Both cities eventually hit a period of decline with a slower transformation that is still on-going with regard to more service-driven cities. Given the important role played by political agents in many regional efforts, it is interesting to consider whether regions and cities such as Silicon Valley have been better able to adapt - e.g. from hardware to design and software creation - due to agency being driven by the market or political intervention. This has contemporary ramifications in terms of state-driven transformations such as those experienced by, for example, massively transforming cities such as Dubai (Alfaki and Ahmed, 2017), and whereby the private sector has played a lesser role in further the development of an entrepreneurial culture and associated institutions. 
Clearly, the source of long-term regional economic success and renewal is to create a behavioural environment that fosters positive lock-in allowing entrepreneurship and innovation to become culturally embedded. As illustrated by Figure 1, this would seem to require agents within regional economic systems that promote institutional and cultural change. In particular, such agents will responsible for creating local economic institutions that are efficient in the sense that they incentivise innovation and help remove barriers to change. What is important to consider is the source of these agents. Whilst all the examples listed in Table 1 included entrepreneurs who interacted with other organisations to create an appropriate culture and the institutions, suggesting that these are intrinsically linked to the actions of key agents and the economic systems within which they operate.

\section{Figure 1 About Here}

\section{Discussion and Conclusion}

From a theoretical perspective, the prevailing discourse on regional development is largely positioned within structural explanations based on varieties of analysis concerning the spatial organisation of industry, with little consideration paid to the role of agents within particular regional structures and systems. However, the analysis presented above indicates that the role of human agency plays a fundamental factor in facilitating development at the regional level, specifically in terms of innovative transformation and evolutionary renewal. This role concerns three key factors: (1) in the lineage of structuration theory, it is the case that the configuration, efficiency and sustainability of the regional ecosystems that push or hinder economic development are a primary result of the actions and agency of a particular cadre of individuals within a specific location; (2) the regional ecosystems of development are contingent on the underlying culture and institutional environment within a specific region, with nature and type of human agency moderating the relationship between this environment and the more tangible economic systems operating within the region; and (3) the mix and interaction of different forms of human agents and agency within a region will determine the nature of the form economic system - e.g. cluster, innovation system or milieu - within this region and subsequently its development trajectory and capacity for innovative transformation and economic renewal.

Building on these theoretical propositions, especially the third, there is a strong indication that across many regions at different points in time the role of entrepreneurship has 
been a pivotal source of agency in fostering development, transformation and renewal. Furthermore, it is interaction of entrepreneurial agency with others forms, such as political and labour agency, that has resulted in particular types of regional economic evolution. Therefore, in likelihood the absence of significant entrepreneurial agency within a city or region it will be unable to achieve sustainable and long-term development, and in line with the second research question outlined earlier, it is necessary to consider how human agency in regions becomes manifest by entrepreneurship. The analysis presented above suggests the following: (1) the confluence of group level culture with a city or region and the personality psychology of individuals within this city or region produces a psychocultural environment that creates certain forms of human agency that may or may not have a propensity toward entrepreneurial traits, especially in the form, for example, of legitimation and moral approval; (2) once again following structuration arguments, the propensity to action upon entrepreneurial traits - i.e. agency - will at least be partly determined by the nature of the underlying regional economic ecosystems, especially with regards to apparent opportunity and economic returns; and (3) finally, the nature of personal, proxy and collective forms of human agency in a city or region will result in a specific variant of entrepreneurial form within this city or region.

To some degree each of the six theoretical propositions indicated above remain somewhat tentative as they are elucidated from a relatively disparate and unbounded range of literature, but they represent a series of notions with the capacity for potential testable empirical analysis. Nevertheless, it is already clear that entrepreneurship is a prerequisite component of agency underlying the regional development process. In economically successful regions, entrepreneurship is harnessed, distributed and capitalised upon through ecosystems of connected agents who create networks, knowledge and institutions that positively and openly evolve to sustain innovation and economic development. Alongside this, economic renewal, transformation and the formation of effective and efficient regional ecosystems will at least be partly determined by the behavioural life of cities and regions in terms of the underlying and dominant cultural and psychological traits of individuals within these places. As argued above, these traits determine the forms of human agency to be found in particular regions, and this agency itself is a determinant of the economic (eco)systems within them.

Human agency necessarily comes in many forms and varieties, but a key form of agency necessary for innovative-led renewal and transformation concerns entrepreneurial agency. Supported by, for example, political and worker agency, entrepreneurs represent the key catalysts of change at the regional level. It appears that throughout history urban and regional transformation has been led by a core group of entrepreneurial agents that have taken a lead in 
positively evolving the economies in which they are physically situated, often through new generations of agent producing innovations that further push forward the technological frontier set by their predecessors. In mature and lagging regional economies it is all too often the case that these types of agents have migrated to other regions with stronger ecosystems and greater opportunities, or that such agents have not been nurtured in the first instance due to the underlying psychocultural traits of the region (Rentfrow et al., 2015). This leaves these regions in an economic situation whereby they lack critical mass in the types of industries and sectors through which value and competitiveness can be best achieved. In other words, it is the capability to facilitate institutional and cultural change - which is likely to be generational that is the centrepiece of regional economic transformation. Therefore, the persistence and reproduction of a cultural and institutional environment that often actively works against an evolutionary trajectory embedded in creating economic systems steeped in entrepreneurship remains, perhaps, the greatest challenge for these regions.

For a policy perspective it is clear that in reality engineering behavioural change is a sensitive endeavour and is not something policymakers can achieve overnight, and although it is undoubtedly impossible to replicate success stories there are lessons that can be learned as to how to go about enhancing entrepreneurship and development. Importantly, there is a need to focus on establishing collective behaviour that catalyses social and knowledge networks between entrepreneurial agents (Fritsch and Kauffeld-Monz, 2008; Huggins and Thompson, 2017b).

Before such networks can be established, however, there is a need to ensure a critical mass of entrepreneurial agents, and whilst boosterism has its critics it does help to generate a strong mix of an appealing living and working environment - in cultural, physical, and business terms - as well as a cluster of stimulating people, businesses, and ideas across a broad cultural spectrum from the arts to high-technology economic activity. Such an environment has the potential to act as a factor in attracting and retaining key agents, with location decisions made by individuals being subject to creative lifestyle issues, which are not always given priority within the formulation of more traditional regional policy (Mellander et al., 2011). Research has indicated that high-quality living is seen by progressive regional policymakers to come in a wide range of forms and guises including diversity, multicultural acceptance, low pollution, high levels of green space and plentiful leisure activity - be this in the shape of night time entertainment or historic and cultural attractions (Florida et al., 2011).

Although the above points to role of policy in attracting, retaining and supporting existing agents, the key to renewal and transformation is likely to lie with the nurturing of 
indigenous entrepreneurial agents. Here perhaps the only route - which is necessarily a longterm one - is through changes within local and regional education systems, especially those that seek to provide individuals with the personalities and mindsets to become the 'extrovert' entrepreneurial agents that are seen to be central to resilient regional ecosystems (Martin and Sunley, 2011). Equally, it should be acknowledged that attempts to modify behaviour and culture through educational programmes may have unknown ramifications that will impact not only on entrepreneurial activity but the socioeconomics of regional development as a whole (Huggins and Thompson, 2016).

From the perspective of future research, the analysis shows a need for the role of entrepreneurial agents to be more fully recognised in the regional development literature, especially to recognise the longer term role and impact of behavioural factors stemming for the underlying culture and institutions present. Unexplored questions are: to what extent and how do entrepreneurial agents influence regional culture and institutions, and what are the factors that lead to the retention (or diminishing) of entrepreneurial personalities and supportive cultures and institutions? Similarly, an apparent fertile area of research concerns an exploration of the key entrepreneurial agents in particular regions, and their impact - both positive and potentially negative. Also, are they individual 'isolated' entrepreneurs, or operating through collective forms of agency, especially with political and other agents who create the right (or wrong) conditions for economic development, innovation and transformation? This leads to further questions regarding the appropriate balance of 'power' to ensure long term success and the wider behavioural life of entrepreneurs within their city or region.

Finally, perhaps one of the key reasons for these questions not being fully answered are the use of current and past analytical approaches that favour one or other perspective. In particular, although approaches based on historical or secondary driven data analysis provide insights, questions concerning the determinants of regional transformation and renewal questions to be answered there needs to be a stronger longitudinal element that is not only restricted to prominent figures, and provides measures of the development of much softer factors.

\section{References}

Alfaki, I. and Ahmed, A. 2017. From Oil to Knowledge: Transforming the United Arab Emirates into a Knowledge-Based Economy. London: Routledge.

Archer, M.S. 1995. Realist Social Theory: The Morphogenetic Approach. New York, NY: Cambridge University Press.

Archer, M.S. 2003. Structure, Agency, and the Internal Conversation. New York, NY: Cambridge University Press. 
Ariely, D. (2008), Predictably Irrational: The Hidden Forces that Shape our Decisions, New York: Harper.

Ayres, S. 2014. Place-based leadership: reflections on scale, agency and theory. Regional Studies, Regional Science, vol. 1, no. 1, 21-24.

Bandura, A. 1997. Self-Efficacy: The Exercise of Self-Control, New York, NY, Freeman.

Bandura, A. 2001. Social cognitive theory: an agentic perspective, Annual Review of Psychology, vol. 52, 1-26

Bandura, A. 2006. Toward a psychology of human agency, Perspectives on Psychological Science, vol. 1, no. 2, 164-80

Barber, B. 2014. If Mayors Ruled the World: Dysfunctional Nations, Rising Cities. New Haven and London: Yale University Press.

Bathelt H, Malmberg A and Maskell P. 2004. Clusters and knowledge: Local buzz, global pipelines and the process of knowledge creation. Progress in Human Geography 28(1): $31-56$.

Beer, A., and Clower, T. 2014. Mobilizing leadership in cities and regions. Regional Studies, Regional Science, 1(1), 5-20.

Beugelsdijk, S. 2009. 'Entrepreneurial culture, regional innovativeness and economic growth', in A. Freytag and R. Thurik (eds), Entrepreneurship and Culture, Heidelberg, Germany and New York, NY, USA: Springer, pp. 129-54.

Boschma, R. and R. Martin 2010. 'The aims and scope of evolutionary economic geography', in R. Boschma and R. Martin (eds), Handbook of Evolutionary Economic Geography, Cheltenham, UK and Northampton, MA, USA: Edward Elgar Publishing, pp. 3-42.

Bright, N.G. 2016. 'The lady is not returning!': educational precarity and a social haunting in the UK coalfields, Ethnography and Education, 11:2, 142-157,

Bristow, G., and Healy, A. 2014. Regional resilience: an agency perspective. Regional Studies, 48(5), 923-935.

Capello, R. and Nijkamp, P. (eds.) 2009. Handbook of Regional Growth and Development Theories, Cheltenham, Edward Elgar

Carlsson, B. 2006. "Internationalization of innovation systems: a survey of the literature." Research Policy 35 (1): 56-67. doi: 10.1016/j.respol.2005.08.003

Chang, H.J. 2013. Hamlet without the Prince of Denmark: How development has disappeared from today's 'development' discourse', in D. Held and C. Roger (eds) Global Governance at Risk, Cambridge, UK: Polity Press, pp. 129-148.

Clark, G.L. 2015. 'Behavior, cognition and context', mimeo, Smith School of Enterprise and the Environment, Oxford University, Oxford.

Coe, N. M. and Jordhus-Lier, D. C. 2011. Constrained agency? Re-evaluating the geographies of labour. Progress in Human Geography, vol. 35, no. 2, 211-33

Cooke, P. 2004. Regional innovation systems: An evolutionary approach. In P. Cooke, M. Heidenreich, and H. Braczyk (Eds.), Regional innovation systems: The role of governance in a globalised world (pp. 1-18). London: Routledge.

Cooke, P. Asheim, B. Boschma, R. Martin, R. Schwartz, D. and Tödtling, F. (eds.) 2011. Handbook of Regional Innovation and Growth, Cheltenham, Edward Elgar

Couttenier, M. and Sangier, M. 2015. Living in the Garden of Eden: mineral resources and preferences for redistribution, Journal of Comparative Economics, vol. 43, no. 2, 24356

Cowling, M., W. Liu, A. Ledger, and N. Zhang. 2015. "What really happens to small and medium sized enterprises in a global economic recession? UK evidence on sales and job dynamics." International Small Business Journal 33 (5): 488-513. doi: $10.1177 / 0266242613512513$ 
Cumbers, A., D. Featherstone, D. MacKinnon, A. Ince, and K. Strauss. 2016. "Intervening in globalization: the spatial possibilities and institutional barriers to labour's collective agency." Journal of Economic Geography 16 (1): 93-108. doi: 10.1093/jeg/lbu039

Cumbers, A., MacKinnon, D., McMaster, R. 2003. Institutions, power and space: assessing the limits to institutionalism in economic geography, European Urban and Regional Studies, 10 (4): 325-342.

Dixon, T., Otsuka, N., \& Abe, H. 2011. Critical success factors in urban brownfield regeneration: an analysis of 'hardcore'sites in Manchester and Osaka during the economic recession (2009-10). Environment and Planning A, 43(4), 961-980.

Dopfer, K. and Potts, J. 2004. Evolutionary realism: a new ontology for economics, Journal of Economic Methodology, 11:2, 195-212.

Dopfer, K. Foster, J. and Potts, J. 2004. Micro-meso-macro, Journal of Evolutionary Economics, 14, 263-279.

Dosi, G. 1988. 'The nature of the innovative process', in S. Dosi, C. Freeman, R. Nelson, G. Silverberg, L. Soete (eds.), Technical Change and Economic Theory, London: Pinter, pp. 221-238.

Drakopoulou Dodd, S. and Anderson, A. R. 2007. Mumpsimus and the mything of the individualistic entrepreneur, International Small Business Journal, vol. 25, no. 4, 34160.

Feldman, M. P., J. Francis, and J. Bercovitz. 2005. "Creating a cluster while building a firm: entrepreneurs and the formation of industrial clusters." Regional Studies 39 (1): 129141. doi: $10.1080 / 0034340052000320888$

Feliciotti, A., Romice, O., \& Porta, S. 2017. Urban regeneration, masterplans and resilience: the case of the Gorbals in Glasgow. Urban Morphology, 21(1).

Ferbrache, F. and Knowles, R. D. 2017. City boosterism and place-making with light rail transit: a critical review of light rail impacts on city image and quality, Geoforum, vol. 80, 103-13.

Florida, R. Mellander, C. and Stolarick, K. 2011. Beautiful places: the role of perceived aesthetic beauty in community satisfaction, Regional Studies, vol. 45, no. 1, 33-48

Florida, R. Adler, P. and Mellander, C. 2017. The city an innovation machine. Regional Studies, vol. 51, no. 1, 86-96.

Fritsch, M. and Kauffeld-Monz, M. 2008. The impact of network structure on knowledge transfer: an application of social network analysis in the context of regional innovation networks, Annals of Regional Science, vol. 44, no. 1, 21-38.

Fritsch, M., and Wyrwich, M. 2015. Does Persistence in Start-up Activity Reflect Persistence in Social Capital? (No. 2015-009). Friedrich-Schiller-University Jena, Max-PlanckInstitute of Economics.

Giddens, A. 1979. Central problems in social theory: action, structure and contradiction in social analysis, Basingstoke, Macmillan

Giddens, A. 1984. The constitution of society: outline of the theory of structuration, Cambridge, Polity Press

Glaeser, E. L. Kerr, S. P. and Kerr, W. R. 2015. Entrepreneurship and urban growth: an empirical assessment with historical mines, Review of Economics and Statistics, vol. 97 , no. 2, 498-520

Gordon, A. 1997. Ghostly Matters: Haunting and the Sociological Imagination. Minneapolis: University of Minnesota Press.

Gradstein, M. and Justman, M. 2000. Human capital, social capital, and public schooling, European Economic Review, vol. 44, no. 4-6, 879-889. 
Hadjimichalis, C. (2006) Non-Economic Factors in Economic Geography and in "New Regionalism': A Sympathetic Critique." International Journal of Urban and Regional Research, 3: 690-704.

Hall, P. 1998. Cities in Civilization, New York, NY, Pantheon Books

Harrison, R. T., Cooper, S. Y., \& Mason, C. M. 2004. Entrepreneurial activity and the dynamics of technology-based cluster development: The case of Ottawa. Urban Studies, 41(5-6), 1045-1070.

Harvey, D., 2003. The New Imperialism, Oxford: Oxford University Press.

Hassink, R. 2005. 'How to unlock regional economies from path dependency? From learning regions to learning cluster', European Planning Studies, 13 (4): 521-535.

Hodgson, G.M. 2007. Meanings of methodological individualism, Journal of Economic Methodology, 14, 211-226.

Holmes, T. J. 2006. 'Geographic spillover of unionism', National Bureau of Economic Research Working Paper, 12025

Hospers, G.-J. 2006. Silicon somewhere? Assessing the usefulness of best practices in regional policy. Policy Studies, vol. 27, no. 1, 1-15

Huggins, R. 2008. The evolution of knowledge clusters: progress and policy. Economic development Quarterly, 22(4), 277-289.

Huggins, R. 2016. 'Capital, institutions and urban growth systems', Cambridge Journal of Regions, Economy and Society, 9, 443-463.

Huggins, R. and Izushi, H. 2007. Competing for Knowledge: Creating, Connecting, and Growing, Abingdon: Routledge

Huggins, R. and Izushi, H. (eds.) 2011. Competition, Competitive Advantage, and Clusters: The Ideas of Michael Porter. Oxford: Oxford University Press.

Huggins, R. and Pugh, R. 2015. Regional competitiveness and Schumpeterian development: Policy evolution in Wales, in Valdaliso, J.M. and Wilson, J.R. (eds) Strategies for Shaping Territorial Competitiveness. Abingdon, Oxon: Routledge.

Huggins, R., and P. Thompson. 2015. "Local entrepreneurial resilience and culture: the role of social values in fostering economic recovery." Cambridge Journal of Regions, Economy and Society 8 (2): 313-330. doi: 10.1093/cjres/rsu035

Huggins, R. and P. Thompson 2016. 'Socio-spatial culture and entrepreneurship: some theoretical and empirical observations', Economic Geography, 92 (3), 269-300.

Huggins, R. and Thompson, P. 2017a. The behavioural foundations of urban and regional development: culture, psychology and agency, Journal of Economic Geography, doi:10.1093/jeg/lbx040.

Huggins, R. and Thompson, P. 2017b. Networks and regional economic growth: a spatial analysis of knowledge ties, Environment and Planning A, vol. 49, no. 6, 1247-65

Huggins, R. Thompson, P. and Obschonka, M. 2018. 'Human behaviour and economic growth: a psychocultural perspective on local and regional development, Environment and Planning A, vol. 50, no. 6, 1269-89. doi: 10.1177/0308518X18778035

Huggins, R. and Williams, N. 2011. Entrepreneurship and regional competitiveness: The role and progression of policy, Entrepreneurship and Regional Development, 23:9-10, 907932.

Hülsbeck, M. and Pickavé, E. N. 2014. Regional knowledge production as determinant of hightechnology entrepreneurship: empirical evidence for Germany, International Entrepreneurship and Management Journal, vol. 10, no. 1, 121-38

Johal, S., Moran, M., \& Williams, K. 2017. Avoiding 'back to the future' policies by reforming the 'foundational economy'. Alternatives to Neoliberalism: Towards Equality and Democracy, 175. 
Jokela, M., W. Bleidorn, M. E. Lam, S. D. Gosling, and P. J. Rentfrow. 2015. "Geographically varying associations between personality and life satisfaction in the London metropolitan area." Proceedings of the National Academy of Sciences of the United States of America 112 (3): 725-730. doi:10.1073/pnas.1415800112

Kibler, E., T. Kautonen, and M. Fink. 2014. "Regional social legitimacy of entrepreneurship: implications for entrepreneurial intention and start-up behaviour." Regional Studies 48 (6): 995-1015. doi: 10.1080/00343404.2013.851373

Lee, N. 2017. Psychology and the geography of innovation, Economic Geography, vol. 93, no. $2,106-130$

Lippmann, S., \& Aldrich, H. 2015. A Rolling Stone Gathers Momentum: Generational Units, Collective Memory, and Entrepreneurship. Academy of Management Review, amr2014.

MacKinnon, D., Cumbers, A. \& Chapman, K., 2002. Learning, innovation and regional development: a critical appraisal of recent debates. Progress in Human Geography, 26(3), pp.293-311.

MacKinnon, D. Cumbers, A. Pike, A. Birch, K. McMaster, R. 2009. Evolution in economic geography: institutions, political economy, and adaptation, Economic Geography, vol. 85 , no. $2,129-50$

Malecki, E.J. 2007. 'Cities and regions competing in the global economy: knowledge and local development policies', Environment and Planning C, 25 (5), 638-54.

Martin, R., \& Sunley, P. 2003. Deconstructing clusters: chaotic concept or policy panacea?. Journal of economic geography, 3(1), 5-35.

Martin, R., Sunley, P. 2006. 'Path dependence and regional economic evolution', Journal of Economic Geography, 6 (4): 395-437.

Martin, R. and Sunley, P. 2011. Conceptualizing cluster evolution: beyond the life cycle model?, Regional Studies, vol. 45, no. 10, 1299-1318

Martin, R., and Sunley, P. 2015. On the notion of regional economic resilience: conceptualization and explanation. Journal of Economic Geography, 15(1), 1-42.

Massey, D. Quintas, P. and Wield, D. 1992. High-Tech Fantasies: Science Parks in Society, Science and Space, London, Routledge

McClelland, D. C. 1967. The Achieving Society. D. van Nostrand, Princeton, NJ.

Mellander, C. Florida, R. and Stolarick, K. 2011. Here to stay - the effects of community satisfaction on the decision to stay, Spatial Economic Analysis, vol. 6, no. 1, 5-24

Mokyr, J. 2015. Intellectuals and the rise of the modern economy. Science, 349(6244), 141142.

Mokyr, J. 2017. A Culture of Growth: The Origins of the Modern Economy, Princeton, NJ, Princeton University Press.

Mole, K.F., and M. Mole 2010. "Entrepreneurship as the structuration of individual and opportunity: a response using a critical realist perspective." Journal of Business Venturing 25 (2): 230-237. doi: 10.1016/j.jbusvent.2008.06.002

Moos, A. I., and M. J. Dear. 1986. Structuration theory in urban analysis: 1. Theoretical exegesis. Environment and Planning A, 18(2), 231-252.

Moretti, E. 2012. The New Geography of Jobs. New York, NY: Houghton Mifflin and Harcourt.

Noorderhaven, N., R. Thurik, S. Wennekers, and A. van Stel. 2004. "The role of dissatisfaction and per capita income in explaining self-employment across 15 European countries." Entrepreneurship Theory and Practice 28 (5): 447-466. doi: 10.1111/j.15406520.2004.00057.x

Obschonka, M., H. Andersson, R. K. Silbereisen, and M. Sverke. 2013a. "Rule-breaking, crime, and entrepreneurship: a replication extension study with 37-year longitudinal 
data." Journal of Vocational Behavior 83 (3): 386-396. doi:

10.1016/j.jvb.2013.06.007

Obschonka, M., E. Schmitt-Rodermund, R.K. Silbereisen, S.D. Gosling and J. Potter 2013b.

'The regional distribution and correlates of an entrepreneurship-prone personality profile in the United States, Germany, and the United Kingdom: a socioecological perspective', Journal of Personality and Social Psychology, 105 (1), 104-22. doi: $10.1037 / \mathrm{a} 0032275$

Obschonka, M., Stuetzer, M., Gosling, S. D., Rentfrow, P. J., Lamb, M. E., Potter, J., and Audretsch, D. B. 2015. Entrepreneurial Regions: do macro-psychological Cultural Characteristics of Regions help solve the "Knowledge Paradox" of Economics?. PloS One, 10(6), e0129332.

Obschonka, M., Stuetzer, P. J., Rentfrow, L, S-T.,Satchell, M., Silbereisen , R. K., Potter, J., Gosling, S. D. 2017. In the shadow of coal: The macro-psychological vestiges of the Industrial Revolution, mimeo.

Peterson, G. 2000. Political ecology and ecological resilience: an integration of human and ecological dynamics, Ecological Economics, vol. 35, no. 3, 323-36

Pike, A., MacKinnon, D., Cumbers, A. 2016. Doing evolution in economic geography, Economic Geography, 92 (2): 123-144.

Piketty, T. 2014.. Capital in the Twenty-First Century. Cambridge: The Belknap Press of Harvard University Press.

Porter, M. E. 1981. The contributions of industrial organization to strategic management. Academy of Management Review, 6(4), 609-620.

Porter, M.E. 1990. The Competitive Advantage of Nations, New York, NY, USA: Free Press.

Rentfrow P J, Gosling S D, Jokela M, Stillwell D J, Kosinski M, Potter J 2013. Divided we stand: Three psychological regions of the United States and their political, economic, social, and health correlates. Journal of Personality and Social Psychology, 105, 9961012.

Rentfrow, P. J. and Jokela, M. 2017. Regional differences in personality: causes and consequences, A. T. Church (ed.) The Praeger Handbook of Personality Across Cultures: Trait Psychology across Cultures, Santa Barbara, CA, Praeger, pp. 225-50

Rentfrow, P. J., M. Jokela, and M. E. Lamb. 2015. "Regional personality differences in Great Britain.” PLOS ONE 10 (3): doi: 10.1371/journal.pone.0122245

Rodríguez-Pose, A. (1998). Social conditions and economic performance: The bond between social structure and regional growth in Western Europe. International Journal of Urban and Regional Research, 22(3), 443-459.

Rowthorn, R., 2010. Combined and Uneven Development: Reflections on the North-South Divide. Spatial Economic Analysis, 5(4), pp.363-388.

Sachs, J. 2000. 'Notes on a new sociology of economic development', in L.E. Harrison and S.P. Huntington (eds), Culture Matters: How Values Shape Human Progress, New York, NY, USA: Basic Books, pp. 29-43.

Sarason, Y., T. Dean, and J. F. Dillard. 2006. "Entrepreneurship as the nexus of individual and opportunity: a structuration view." Journal of Business Venturing 21 (3): 286-305. doi: 10.1016/j.jbusvent.2005.02.007

Sarason, Y., J. F. Dillard, and T. Dean. 2010. "How can we know the dancer from the dance?" Journal of Business Venturing 25 (2): 238-243. doi: 10.1016/j.jbusvent.2008.06.003

Saxenian, A., 1994. Regional advantage: culture and competition in Silicon Valley and Route 128, Cambridge, Massachusetts: Harvard University Press.

Saxenian, A. 2006. The New Argonauts: Regional advantage in a global economy. Cambridge, Mass.: Harvard University Press. 
Saxenian, A., \& Sabel, C. 2008. Roepke lecture in economic geography: Venture capital in the "periphery": the new argonauts, global search, and local institution building. Economic Geography, 84(4), 379-394.

Shearmur, R., C. Carrincazeaux, and D. Doloreux 2016. 'The geographies of innovations: beyond one-size-fits-all', in R. Shearmur, C. Carrincazeaux, and D. Doloreux (eds), Handbook on the Geographies of Innovation, Cheltenham, UK and Northampton, MA, USA: Edward Elgar, pp. 1-21.

Smallbone, D., D. Deakins, M. Battisti, and J. Kitching. 2012. "Small business responses to a major economic downturn: empirical perspectives from New Zealand and the United Kingdom.” International Small Business Journal 30 (7): 754-777.

Spigel, B. (2013). Bourdieuian approaches to the geography of entrepreneurial cultures. Entrepreneurship \& Regional Development, 25(9-10), 804-818.

Spigel, B. (2017). The relational organization of entrepreneurial ecosystems. Entrepreneurship Theory and Practice, 41(1), 49-72.

Stimson, R., R.R. Stough and W. Salazar 2009. Leadership and Institutions in Regional Endogenous Development, Cheltenham, UK and Northampton, MA, USA: Edward Elgar.

Stimson, R. Stough, R. R. and Nijkamp, P. (eds.) 2011. Endogenous regional development: perspectives, measurement and empirical investigation, Cheltenham, Edward Elgar

Stoerring, D., and B. Dalum. 2007. "Cluster emergence: a comparative study of two cases in North Jutland, Denmark." In Creative Regions: Technology, Culture and Knowledge Entrepreneurship, edited by P. Cooke, and D. Schwartz, 127-147. Abingdon: Routledge.

Storper, M. 2010. 'Why does a city grow? Specialisation, human capital or institutions?', Urban Studies, 47 (10), 2027-50.

Storper, M. 2013. Keys to the City: How Economics, Institutions, Social Interaction and Politics Shape Development, Oxford, UK and Princeton, NJ, USA: Princeton University Press.

Stuetzer, M., Obschonka, M., Audretsch, D. B., Wyrwich, M., Rentfrow, P. J., Coombes, M., Shaw-Taylor, L., and Satchell, M. 2016. Industry structure, entrepreneurship, and culture: an empirical analysis using historical coalfields. European Economic Review 86(1): 52-72.

Tabellini, G. 2010. 'Culture and Institutions: Economic Development in the Regions of Europe', Journal of the European Economic Association, 8 (4), 677-716.

Ter Wal, A. and R. Boschma 2011. 'Co-evolution of firms, industries and networks in space', Regional Studies, 45 (7), 919-33.

Thompson, P., and R. Huggins. 2018. "Self-employment and the relationship between personality and culture." Paper presented at the Institute for Small Business and Entrepreneurship Conference, Birmingham, November 7-8.

Thompson, P., and W. Zang. 2018. "The foreign business and domestic enterprise relationship: its implications for local entrepreneurial resilience." Local Economy 33 (1): 10-37. doi: $10.1177 / 0269094218756817$

Tubadji, A. 2013. 'Culture-based development - culture and institutions: economic development in the regions of Europe', Society Systems Science, 5 (4), 355-91.

Tubadji, A., and Nijkamp, P. 2015. Cultural impact on regional development: application of a PLS-PM model to Greece. The Annals of Regional Science, 54(3), 687-720.

Uhlaner, L., and R. Thurik. 2007. "Postmaterialism influencing total entrepreneurial activity across nations." Journal of Evolutionary Economics 17 (2): 161-185. doi: 10.1007/s00191-006-0046-0 
Wolfe, D. A. 2017. Innovation and creativity in city-regions, in Shearmur, R. Carrincazeaux, C. and Doloreux, D. (eds.) Handbook on the Geographies of Innovation, Cheltenham, Edward Elgar, pp. 174-86.

Zucker, L. G., Darby, M. R., \& Armstrong, J. 1998. Geographically localized knowledge: spillovers or markets?. Economic Inquiry, 36(1), 65-86. 
Figure 1: Behavioural Sources of Positive and Negative Regional Lock-In

\begin{tabular}{|c|c|c|}
\hline & Positive Lock-In Regions & Negative Lock-in Regions \\
\hline Agents & $\begin{array}{l}\text { Agents Promoting Institutional and } \\
\text { Cultural Change }\end{array}$ & $\begin{array}{l}\text { Agents Promoting Institutional and } \\
\text { Cultural Persistence }\end{array}$ \\
\hline Culture & $\begin{array}{c}\text { Cultural Change and Diversity Across } \\
\text { Time }\end{array}$ & $\begin{array}{l}\text { Cultural Reproduction and Homophily } \\
\text { Across Time }\end{array}$ \\
\hline Institutions & Economically Efficient Institutions & Rent Seeking Institutions \\
\hline
\end{tabular}


Table 1: Agents of Innovation, Transformation and Development for a Cross Section of Cities and Regions at Key Points in their Evolution

\begin{tabular}{|c|c|}
\hline City (time period) & Key Agents \\
\hline $\begin{array}{l}\text { Silicon Valley/Bay Area (1950 } \\
\text { 1990) }\end{array}$ & $\begin{array}{l}\text { Alexander M. Poniatoff (1944-1956); Bill Gates (1981); Charles Litton (1932); Cy Elwell (1909); } \\
\text { Ed Roberts, Leslie Solomon, Roger Melen (1974); Frederick Terman (1951); Gary Kildall } \\
\text { (1973); Harold Lindsay (1947-1956); Lee De Forest (1906); Robert Noyce (1956); Stephen } \\
\text { Wozniak\& Steven Jobs (1976); William Weber, Sigurd Varian and Russell Varian (1939). }\end{array}$ \\
\hline Los Angeles (1910-1945) & $\begin{array}{l}\text { Adolph Zukor (1903-06); Alexander Black (1893-1994); Thomas Armat and Charles Francis } \\
\text { Jenkins (1895-1896); Carl Laemmle (1912); David W. Griffith (1915); Harry Cohn (1920); Horace } \\
\text { Henderson Wilcox (1883); John P. Harris and Harry Davis (1905); Louis B. Mayer (1924); } \\
\text { Thomas Alva Edison (1887-1889); Harry, Albert, Sam and Jack Warner (1918); William Fox } \\
\text { (1903). }\end{array}$ \\
\hline New York (1880-1940) & $\begin{array}{l}\text { Alexander G. Bell (1876); Clifford M. Holland (1919-1927); John B. Dunlop (1888); Thomas } \\
\text { Alva Edison (1879); Frank Julian (1887); John Augustus (1844); John Francis Hylan (Red } \\
\text { Mike) (1920s); Fiorello La Guardia (1934-1940); Ottmar Mergenthaler (1885); Othmar } \\
\text { Hermann Ammann (1931); Robert Fulton (1807); George Westinghouse (1868); William J. } \\
\text { Wilgus (1903-1913). }\end{array}$ \\
\hline Berlin (1840-1930) & $\begin{array}{l}\text { Emil Rathenau (1889-90); Frank J. Sprague (Late 1880s); Friedrich Wilhelm Anton von Heynitz } \\
\text { (1778-1799); Sir Humphry Davy (1808); John Gibbs and Lucien Gaulard (1880); Nikola Tesla } \\
\text { (1887); Samuel Morse (1837); Werner von Siemens (1879). }\end{array}$ \\
\hline Detroit (1890-1915) & $\begin{array}{l}\text { Charles E. Duryea \& J. Frank Duryea (1893); Gottlieb Daimler \& Karl Benz (1885); Etienne } \\
\text { Lenoir (1860); Henry Ford, Ransom E. Olds and Charles B. King (1870s-1890s); Oliver Evans } \\
\text { (1875); Nicolaus A. Otto (1876); Ransom E. Olds (1899); Alfred P. Sloan (1918 onwards); } \\
\text { Wilhelm Maybach (1893). }\end{array}$ \\
\hline London (1825-1900) & $\begin{array}{l}\text { Jeremy Bentham (1784); Sir Edwin Chadwick (1839-1942); Dr. John Snow (1849); Henry } \\
\text { Fielding (1750); John Howard, Sir William Blackstone and William Eden (1778); John Nash } \\
\text { (1820s); Lord John S. Eldon (1819); Lord Charles Grey (1830); Lord John Russell (1839); }\end{array}$ \\
\hline
\end{tabular}




\begin{tabular}{|c|c|}
\hline & $\begin{array}{l}\text { Messrs Haden of Trowbridge (1842); Prince of Wales (1865); Colonel Sir Charles Rowan \& Sir } \\
\text { Richard Mayne; William Allen (1817); William Farr (1841). }\end{array}$ \\
\hline Glasgow (1770-1890) & 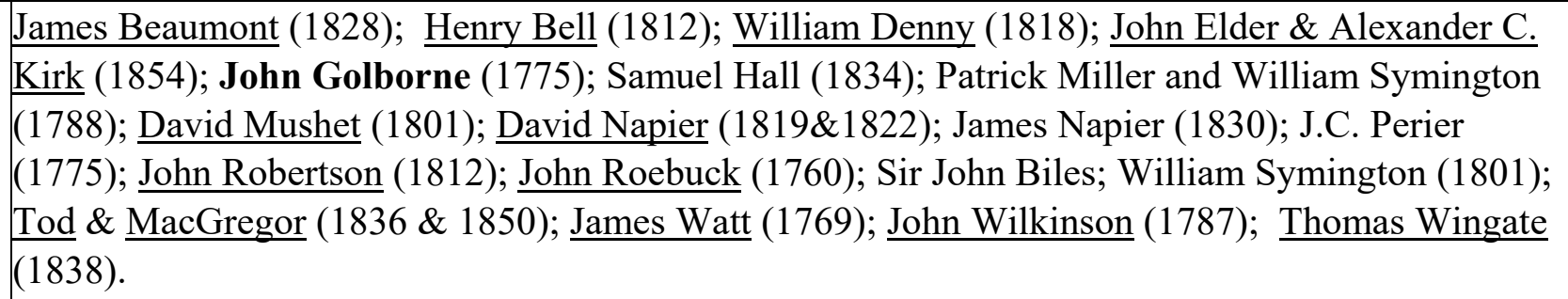 \\
\hline Manchester (1760-1830) & $\begin{array}{l}\text { John Aikin (1795); Richard Arkwright (1771); Edmund Cartwright (1786); Peter Clare (1778); } \\
\text { Samuel Crompton (1779); Abraham Darby (1709); Edward III (1400); William Galloway (1790); } \\
\text { Grimshaw of Gorton (1790); James Hargreaves (1765); John Kay (1733); William Lee (1589); } \\
\text { Thomas Lombe (1721); Robert Peel ; Richard Roberts (1825); Andrew Ure (1835); John Wyatt } \\
\text { \& Lewis Paul (1741). }\end{array}$ \\
\hline Rome (50 BC-AD 100) & $\begin{array}{l}\text { Augustus Caesar (22BC); Appius Claudius Caecus (312BC); Julius Caesar ( } 1^{\text {st }} \text { and } 2^{\text {nd }} \text { century } \\
\text { and } 7^{\text {th }} \text { BC); Claudius (52AD); Domitian; Sextus Julius Frontinus (96AD); Marcus Vipsanius } \\
\text { Agrippa (20BC\&12BC); Gaius Sergius Orata (1200 BC); Quintus Marcius Rex (144 BC); } \\
\text { Septimus Severus (191AD); Marcus Vitruvius Pollio (30BC-15BC). }\end{array}$ \\
\hline
\end{tabular}

Source: Based on the Authors' Analysis of Hall (1998) and other materials; unlined names are those founding businesses as entrepreneurs; those in bold are stakeholders with key responsibility for developing the institutions and infrastructure that allow entrepreneurship to flourish; others are largely inventors and innovators working for others when they made their main contribution. 
Table 2: Agents of Innovation, Transformation and Development in Manchester 1760-1830

\begin{tabular}{|c|c|c|c|}
\hline Agent & Occupation: & Year (Time): & Key Contribution to Economic Development \\
\hline Edward III & Monarch & 1400 & $\begin{array}{l}\text { Brought Flemish weavers to settle in various places in the } \\
\text { north of England including Manchester, Rossendale and } \\
\text { Pendle in 14th century (latterly the Weaver's Act } 1558 \\
\text { freed the weaving industry from medieval regulations, and } \\
\text { thus Lancashire enjoyed a rare degree of economic } \\
\text { freedom }\end{array}$ \\
\hline William Lee & Clergyman & 1589 & $\begin{array}{l}\text { Invented stocking frame, creating complex domestic } \\
\text { production }\end{array}$ \\
\hline Abraham Darby & Ironmaster and Quaker & 1709 & Smelted iron with coal \\
\hline Thomas Lombe & Silk-thrower & 1721 & Built first recognisable factory \\
\hline John Kay & Innovators and Industrialist & 1733 & $\begin{array}{l}\text { Innovated flying shuttle which increased the efficiency of } \\
\text { weaving two-fold. This eventually created pressure on the } \\
\text { supply of weft needed for weave }\end{array}$ \\
\hline John Wyatt \& Lewis Paul & Carpenter \& Innovator & 1741 & $\begin{array}{l}\text { Innovated and applied the system of spinning cotton by } \\
\text { rollers }\end{array}$ \\
\hline James Hargreaves & Weaver, Carpenter & 1765 & $\begin{array}{l}\text { Invented the spinning jenny which reduced the labour } \\
\text { required to produce yarn }\end{array}$ \\
\hline Peter Clare & Clockmaker & 1778 & $\begin{array}{l}\text { Proposed to establish philosophical school emphasising the } \\
\text { mechanics and similar subjects }\end{array}$ \\
\hline Samuel Crompton & Biographer, Industrialist & 1779 & $\begin{array}{l}\text { Invented the mule machine, which was cheap, compact, } \\
\text { light and w could be hand-operated in an ordinary house }\end{array}$ \\
\hline
\end{tabular}




\begin{tabular}{|c|c|c|c|}
\hline Edmund Cartwright & Professor of Poetry & 1786 & $\begin{array}{l}\text { Improved weaving machine model which stopped if the } \\
\text { thread was accidentally broken }\end{array}$ \\
\hline Robert Peel & Industrialist & 1787 & $\begin{array}{l}\text { Improved the factory system. In } 1787 \text { he built an integrated } \\
\text { spinning, weaving and printing factory }\end{array}$ \\
\hline William Galloway & $\begin{array}{l}\text { Mining engineer, Professor, } \\
\text { and Industrialist }\end{array}$ & 1790 & Established firms to make water wheels \\
\hline Richard Roberts & Millwright & 1825 & $\begin{array}{l}\text { Developed self-acting mule in } 1825 \text { at the request of the } \\
\text { manufacturers who were afflicted by the strikes of } \\
\text { spinners. }\end{array}$ \\
\hline Richard Arkwright & Economist, Industrialist & 1771 & $\begin{array}{l}\text { Arkwright did the most to make the spinning machine } \\
\text { useful for production }\end{array}$ \\
\hline Grimshaw of Gorton & Industrialist & 1790 & Developed Power loom \\
\hline
\end{tabular}

Source: Based on the Authors' Analysis of Hall (1998) 
Table 3: Agents of Innovation, Transformation and Development in Glasgow 1770-1890

\begin{tabular}{|c|c|c|c|}
\hline Agent & Occupation: & Year (Time): & Key Contribution to Economic Development \\
\hline James Watt & Instrument maker & 1769 & Invented Watt Steam Engine \\
\hline Sir John Biles & Professor & & Devised new means of turbine efficiency \\
\hline John Roebuck & Inventor and Industrialist & 1760 & Established first Scottish blast furnaces \\
\hline John Golborne & $\begin{array}{l}\text { Contactor, Navigation } \\
\text { engineer }\end{array}$ & 1775 & Deepened the Clyde Channel \\
\hline Robert Wilson & Founder of blast furnaces & 1780 & Set up a foundry with first furnace \\
\hline John Wilkinson & Ironmaster & 1787 & $\begin{array}{l}\text { Iron was first used in part-construction of a barrage called } \\
\text { 'Trial' }\end{array}$ \\
\hline $\begin{array}{l}\text { Patrick Miller and William } \\
\text { Symington }\end{array}$ & Banker and Engineer & 1788 & $\begin{array}{l}\text { Sailed steamboat on Dalswinton lake. The speed of the } \\
\text { boat was about } 5 \text { miles per hour }\end{array}$ \\
\hline David Mushet & Engineer & 1801 & $\begin{array}{l}\text { Found that materials mined in the district abandoned as } \\
\text { "wild coal"contained at least } 30-50 \% \text { iron when raw and up } \\
\text { to } 70 \% \text { when calcined }\end{array}$ \\
\hline William Symington & Engineer and Inventor & 1801 & Fitted a steamboat with a Watt engine \\
\hline Henry Bell & Steamboat developer & 1812 & Started first commercial steamship services \\
\hline John Robertson & Engineer & 1812 & $\begin{array}{l}\text { The original 'Comet' engine was developed. He developed } \\
\text { it mainly for land travel }\end{array}$ \\
\hline William Denny & Ship builder & 1818 & Built 30 horsepower engines \\
\hline
\end{tabular}




\begin{tabular}{|l|l|l|l|}
\hline David Napier & Marine engineer & $1819 \& 1822$ & $\begin{array}{l}\text { Built the boiler for 'Comet' and engines for the Talbot. } \\
\text { Also established the first commercial steamship line } \\
\text { between Liverpool, Greenock and Glasgow }\end{array}$ \\
\hline James Beaumont & Manager & 1828 & $\begin{array}{l}\text { Discovered how to use hot instead of cold air in furnace } \\
\text { blast }\end{array}$ \\
\hline James Napier & Engineer and Inventor & 1830 & $\begin{array}{l}\text { Invented the horizontal tubular boiler, giving 25-30 percent } \\
\text { fuel saving }\end{array}$ \\
\hline Samuel Hall & Engineer & 1834 & $\begin{array}{l}\text { Patented a condenser } \\
\text { passenger traffic by iron steamship }\end{array}$ \\
\hline DavidTod \& John MacGregor & Engineers and Shipbuilders & $1836 \& 1850$ & $\begin{array}{l}\text { Made the first Glasgow based transatlantic steam voyage in } \\
1838, \text { the 'British Queen' }\end{array}$ \\
\hline Thomas Wingate & Engineer & 1838 & $\begin{array}{l}\text { Elder's compound engine of 1854 and Kirk's triple- } \\
\text { axpansion engine of 1886 offered price and speed } \\
\text { advantages }\end{array}$ \\
\hline Kirk & Engineer & 1854 & \\
\hline
\end{tabular}

Source: Based on the Authors' Analysis of Hall (1998) 